\title{
Zadania rodziny w ujęciu ks. prof. Jerzego Bajdy
}

Problematyka dotycząca zadań rodziny była często podejmowana w publikacjach, wykładach czy analizach ks. prof. Jerzego Bajdy.

$\mathrm{W}$ swoich rozważaniach $\mathrm{w}$ tym zakresie ks. Bajda często nawiązywał do: adhortacji apostolskiej Familiaris consortio (1981) o zadaniach rodziny chrześcijańskiej we współczesnym świecie; Karty Praw Rodziny (1983); ważnej publikacji "Mężczyzną i niewiasta stworzył ich”. Odkupienie ciała a sakramentalność małżeństwa (1986) czy do Listu do Rodzin (1994), ogłoszonego z okazji Międzynarodowego Roku Rodziny. Nawiązywał także do problematyki małżeństwa i rodziny podejmowanej w papieskich przemówieniach.

Problematykę rodzinną ks. prof. Jerzy Bajda podjął także, pisząc „Listy z Mediolanu”" To wy-

1 J. Bajda, Listy z Mediolanu, „Sprawy Rodziny 98 (2012), nr 2, s. 34-67.
- Wprowadzenie

- Znaczenie prawdy

o człowieku

- Zadania rodziny

- Odkrycie powołania rodziny

- Tworzenie prawdziwej wspólnoty komunii osób

- Otwarcie na życie i służba życiu

- Rodzina szkołą bogatszego człowieczeństwa - Uczestniczenie w rozwoju społeczeństwa

- Troska o właściwe rozumienie pracy - Rodzina jest powołana do radosnego przeżywania świąt - Uczestniczenie w życiu Kościoła

- Troska o uświęcanie siebie i innych

- Dawanie świadectwa - Podsumowanie 
rażenie „z Mediolanu” miało charakter symboliczny. Ks. prof. Bajda nie był w Mediolanie w czasie Światowego Spotkania Rodzin, ale przestudiował materiały z Kongresu Teologiczno-Pastoralnego, jaki odbył się w związku ze Spotkaniem Rodzin. Jak sam napisał - czuł się „owładnięty” treściami Kongresu i zaproszony, by je przemyśleć: nie tylko przemyśleć dla siebie, ale także podzielić się refleksjami z - jak to określił - przyjaciółmi (bo dla ks. prof. Bajdy każdy był przyjacielem), którzy się tą tematyką interesują. Postanowił to uczynić w formie „Listów”.

\section{Wprowadzenie}

Zanim przeanalizuję te zadania rodziny, na które ks. prof. Bajda zwracał szczególną uwagę, przywołam to, co było jego szczególną troską w podejmowaniu kwestii rodziny - znaczenie prawdy o człowieku w spojrzeniu na rodzinę.

\section{Znaczenie prawdy o człowieku}

Ks. Bajda stawia mocny postulat powrotu do pełnej prawdy o człowieku. Trzeba poszerzyć wizję człowieka, przejść od koncepcji jednostki do koncepcji osoby jako podmiotu duchowo-cielesnego, obdarzonego samoświadomością i wolnością, podmiotu wyjątkowego i niepowtarzalnego, zdolnego do nawiązania relacji, jak i do autotranscendencji, powołanego do miłowania innych, jak i samego siebie, do zintegrowania miłości-erosa z miłością-agape, do realizowania siebie w pełni przez dar z siebie dla innych i Boga. Człowiek powinien być otwarty na prawdę, dobro i piękno.

Ks. Bajda podkreśla, że warto zwrócić uwagę na to, iż takie wartości człowieczeństwa, jak samoświadomość, wolność, autotranscendencja, nie wytrzymują próby czasu w momentach wyjątkowych i dramatycznych, kiedy człowiek musi rzucić wszystko na jedną szalę. Wtedy tym, co oświeca sumienie i daje siłę do podjęcia decyzji, jest świadomość, że Bóg ma wobec mnie szczególne życzenie, które mogę nazwać wolą Bożą, przykazaniem Bożym, planem Bożym czy jeszcze inaczej. Bo człowiek rozpoznaje właściwie głos sumienia czy wołanie powinności, czy imperatyw wezwania Bożego wtedy, kiedy rozumie, że jego „autotranscendencja” to nie jakaś formułka metafizyczna, lecz 
prawda, że jesteśmy ukryci w dłoniach Bożych od początku życia do końca życia tu, na ziemi, i zostaliśmy powołani, aby swą własną decyzją skierować całą naszą egzystencję ku zjednoczeniu z miłością Boga.

W swoich rozważaniach ks. Bajda często nawiązuje do filozofii Rocco Buttiglionego, który pokazuje, w jaki sposób tajemnica osoby rzuca światło na istotę rodziny, i równocześnie, w jaki sposób tajemnica rodziny wyjaśnia sens bycia osobą ${ }^{2}$. Niestety dzisiaj nauka zapomniała o osobie i wszystkie nowoczesne teorie polityczne odnoszą się jedynie do „jednostki”, a nie do osoby.

\section{Zadania rodziny}

\subsection{Odkrycie powołania rodziny}

Ks. Bajda podkreślał, iż żaden człowiek, nawet najdoskonalej uformowany personalistycznie i aksjologicznie, nie potrafi, nie ma władzy zadecydować: „ja chcę założyć sobie rodzinę”. To przekracza bezwzględnie jego kompetencje. Człowiek może założyć warsztat czy przedsiębiorstwo, ale nie może własną mocą założyć rodziny. Rodzina jest - jak podkreśla Ksiądz Profesor - szczególnym dziełem Bożym, do którego Bóg powołuje człowieka, aby w ramach tego dzieła pełnił wolę Bożą.

Zdaniem ks. Bajdy nie brakuje dziś - jak to określa - zuchwalców, którzy usiłują własnym przemysłem „stworzyć rodzinę”, zmieniając dowolnie jej komponenty i organizując płodność metodą technologiczną. Takie samowolne twory nie mogą w żaden sposób nazywać się rodziną.

Rodziny nie można pojąć bez odwołania się do tajemnicy stworzenia. Bóg stwarza rodzinę (według świadectwa Księgi Rodzaju), kiedy stwarzając mężczyznę i kobietę, równocześnie czyni ich małżeństwem, to jest taką mistyczną jednością, której mocą zostają powołani, by z rąk Bożych przyjmować nowe życie z miłością.

Rodzina jest zbudowana na małżeństwie mężczyzny i kobiety. Małżeństwo jako fundament rodziny jest tą formą współdziałania z Bogiem, dzięki której tajemnica stworzenia trwa przez wieki, a wraz z nią miłość Stwórcy objawia się u zarania ludzkiego istnienia, przez które Bóg staje się darem dla człowieka.

2 R. Buttiglione, L'uomo e la famiglia, Roma 1990. 
Prawdziwa tożsamość małżeństwa opiera się na relacji oblubieńczej, na przymierzu zawartym przez mężczyznę i kobietę aktem nieodwołalnej osobistej zgody. Małżeństwo, konstytuując rodzinę, stanowi podstawę jej tożsamości. Społeczność rodzinna jest zatem konsekwencją i niejako kontynuacją małżeństwa zawartego przez dwoje połączonych miłością ludzi.

W „Listach z Mediolanu” ks. Bajda pisze, że dom-rodzina jest przez analogię definiowana jako świątynia, w której rodzina jednoczy się, zwracając się do Boga jako Ojca. Stosownie do wymagania, jakie znajduje się w Ewangelii (Mt 7, 24-25), dom powinien być zbudowany na skale. Jest nią jak wiadomo, małżeństwo, o czym już mówi Księga Rodzaju. Ów fundament domu stanowi jedność dwojga ustanowiona „na początku”.

Rodzina stanowi najbardziej pierwotny wyraz natury społecznej człowieka, którego Bóg nie powołał do życia w samotności, ale stworzył jako mężczyznę i niewiastę - parę stanowiącą pierwszą komunię osób. W akcie stwórczym można więc odnaleźć źródło, z którego pochodzą małżeństwo i rodzina. Bóg, który sam jest Miłością, łączy mężczyznę i niewiastę nierozerwalnym węzłem miłości małżeńskiej oraz wierności, czyniąc ich związek rzeczywistością świętą, środowiskiem objawiania się Boskiej mocy, obrazem doskonałej miłości Trójcy Świętej.

\subsection{Tworzenie prawdziwej wspólnoty - komunii osób}

Ks. Bajda powołując się na dzieło Mężczyznq i niewiasta stworzył ich, podkreśla za papieżem:

Obrazem i podobieństwem Boga stał się człowiek nie tylko przez samo człowieczeństwo, ale także przez Komunię osób, którą stanowi od początku mężczyzna i niewiasta. Człowiek staje się odzwierciedleniem Boga nie tyle w akcie samotności, ile w akcie komunii. Człowiek prawdziwie sobą staje się wtedy, gdy z samego siebie uczyni wolny dar, co jest możliwe dzięki podstawowej ludzkiej zdolności jaką jest transcendencja.

W „Listach z Mediolanu” Ksiądz Profesor pisze:

Bóg stwarzając człowieka na Swój obraz, nie stworzył go trojakim, lecz stworzył tylko dwoje. Ci dwoje w kontekście tego samego dzieła stwo- 
rzenia (tajemnicy stworzenia) zostają ustanowieni jednością. W stworzeniu człowieka „jedność" i „mnogość” występująca równocześnie pozwala stwierdzić, że Bóg stwarza człowieka na obraz swojej „Jedności mnogiej”. Obraz Boży w człowieku tkwi nie tyle w oddzielnych osobach, lecz w „jedności dwojga”, czyli w komunii osób, które żyją w relacji wzajemnego bezinteresownego daru. Ta jedność osób jest wielowymiarowa, i komplementarność, która tu zachodzi, dokonuje się na wszystkich poziomach ludzkiego bytu³.

Ks. Bajda za Janem Pawłem II podkreśla:

Człowiek staje się odzwierciedleniem Boga nie tyle w akcie samotności, ile w akcie komunii. Jest wszakże nie tylko obrazem, w którym się odzwierciedla samotność panującej nad światem Osoby, ale niezgłębiona istotowo Boska Komunia Osób. Człowiek prawdziwie staje się sobą wtedy, gdy z samego siebie uczyni wolny dar, co jest możliwe dzięki podstawowej ludzkiej zdolności, jaką jest transcendencja. Najgłębsze zjednoczenie dwojga osób w miłości następuje w więzi małżeńskiej, w której małżonkowie otwierając się na siebie, wzajemnie stają się bezinteresownym darem z siebie. Małżonkami są więc po prostu ci, którzy winni są sobie nawzajem wspólnotę życia i miłości ${ }^{4}$.

Rodzina stanowi początek, źródło i punkt zbieżny relacji międzyludzkich. Leży u podstaw narodu i społecznej świadomości. Rodzina jako pierwsza historyczna społeczność jest niejako pierwowzorem każdej społeczności, pierwotnym i podstawowym źródłem każdej więzi społecznej. Jest podstawową formą współżycia ludzkiego, odpowiadającą najistotniejszym potrzebom człowieka. Stanowi rdzeń społeczeństwa, warunkujący jego właściwy rozwój i trwanie, utrzymanie życia i zachowanie rodzaju ludzkiego. Dobro rodziny domaga się struktur jej organizacji i hierarchii władzy, różnych form praw i obowiązków oraz odpowiedzialności. Życie rodzinne suponuje suwerenność prawno-społeczną rodziny oraz monogamiczność i nierozerwalność małżeństwa, stanowiące przejaw prawa naturalnego.

3 J. Bajda, Listy z Mediolanu, „Sprawy Rodziny” 98 (2012), nr 2, s. 38-39.

4 J. Bajda, Listy z Mediolanu, dz. cyt., s. 37. 
Warto tutaj przytoczyć wypowiedź Jana Pawła II z homilii wygłoszonej w sanktuarium Św. Józefa w Kaliszu. Papież zauważa:

Prawdziwa miłość nigdy nie wygasa. Staje się źródłem siły i wierności małżeńskiej. Rodzina chrześcijańska, wierna swemu sakramentalnemu przymierzu, staje się autentycznym znakiem bezinteresownej i powszechnej miłości Boga do ludzi. Ta miłość Boga stanowi duchowe centrum rodziny i jej fundament. Poprzez tę miłość rodzina powstaje, rozwija się, dojrzewa i jest źródłem pokoju i szczęścia dla rodziców i dla dzieci. Jest prawdziwym gniazdem życia i jedności ${ }^{5}$.

Wydaje się, że aby rodzina mogła doświadczać pełni komunii i uczestnictwa, jest konieczne, żeby relacje między jej członkami ożywiała, kształtowała i wzmacniała czynna miłość i duch ofiary.

Ks. prof. Bajda przytacza wypowiedź Jana Pawła II z katechezy o małżeństwie, w której papież podkreśla, iż małżonkowie Tobiasz i Sara nie tyle rozmawiają ze sobą, ile przemawiają jednym głosem, który jest równocześnie językiem liturgii, czyli modlitwy.

W tym jednym głosie mężczyzna i kobieta są zjednoczeni ze sobą nie tylko wspólnotą serc, ale także jednością dwojga, wychodzących na spotkanie wielkiej próby: próby życia i śmierci [...]. Ten głos - modlitwa - pozwala im obojgu przekroczyć „sytuację graniczną”, sytuację zagrożenia złem, zagrożenia śmiercią, otwierając się całą jednością dwojga w stronę Boga żywego. Modlitwa Tobiasza jest poniekąd najgłębszym profilem liturgii, której słowo jest słowem mocy ${ }^{6}$.

Podstawowe zadania rodziny są określone właśnie przez miłość. Każdy członek rodziny zobowiązany jest do codziennego, permanentnego budowania komunii osób, by czynić w ten sposób z rodziny szkołę bogatszego człowieczeństwa.

5 Jan Paweł II, Homilia wygłoszona w czasie Mszy św. odprawianej przed sanktuarium św. Józefa (Kalisz, 4 czerwca 1997 r.), w: Jan Paweł II, Dzieła zebrane, Kraków 2008, t. IX, s. 705.

6 Jan Paweł II, "Mężczyznq i niewiastą stworzył ich". Odkupienie ciała a sakramentalność małżeństwa, Watykan 1986, s. 449. 


\subsection{Otwarcie na życie i służba życiu}

Sama jedność dwojga nie wystarcza, by stworzyć rodzinę. Konieczne jest otwarcie się na trzeci wymiar: na płodność, na pełnię. Męskość i kobiecość w osobowym zjednoczeniu uzyskują zdolność realizacji pełni życia, do której nie są zdolne pojedyncze osoby. Rodzina otwarta na trzeci wymiar dysponuje ogromnym dynamizmem zdolnym do tworzenia i kształtowania życia, co jest możliwe zawsze „z pomocą Jahwe”, jak to stwierdziła Ewa (Rdz 4, 1).

Miłość małżeńska, będąca szczególnym odzwierciedleniem tajemnicy życia i miłości samego Boga, nastawiona jest na przekazywanie życia i wychowanie potomstwa, które jest jej uwieńczeniem i najpiękniejszym darem Bożym.

Spełniając swój podstawowy obowiązek, a zarazem główną misję, małżonkowie stają się współpracownikami i wyrazicielami ojcowskiej miłości Boga, poprzez rodzenie współuczestniczą także w tajemnicy przekazywania obrazu i podobieństwa Bożego z człowieka na człowieka. Jan Paweł II przypominając prawdę, że rodzina stanowi niejako kolebkę życia i miłości, w której rodzi się i wzrasta każda osoba ludzka, apeluje:

Trzeba odkryć na nowo, że rodzina jest sanktuarium życia. Istotnie bowiem jest ona święta: jest miejscem, w którym życie, dar Boga, może w sposób właściwy być przyjęte i chronione przed licznymi atakami, na które jest ono wystawione, może też rozwijać się zgodnie z wymogami prawidłowego ludzkiego wzrostu. Wbrew tak zwanej kulturze śmierci rodzina stanowi ośrodek kultury życia ${ }^{7}$.

Życie ludzkie posiada bowiem nienaruszalną wartość i najwyższą godność, każda ludzka istota została stworzona przez Boga z miłości i do miłości, powołana do uczestnictwa w Jego wiecznym życiu. Na rodzinie spoczywa zatem szczególna odpowiedzialność, a mianowicie służba życiu i jego obrona od chwili poczęcia aż do naturalnej śmierci, obrona tak istotna w świecie, w którym ustawicznie ścierają się ze sobą dwie antagonistyczne cywilizacje - cywilizacja życia i cywilizacja śmierci.

Dzięki płodnej miłości małżeństwo uczestniczy w misterium stworzenia. Miłość dlatego jest płodna, ponieważ w niej Bóg Stwórca jest obecny

7 Jan Paweł II, Enc. Centesimus annus, nr 39. 
i małżonkowie prawdą swej małżeńskiej miłości uczestniczą w Jego stwórczej miłości. Małżeństwo jest płodne mocą Boga, udzielającego płodności małżonkom, którzy złączeni mocą sakramentu działają przez uczestnictwo w Jego miłości.

Zaistnienie człowieka nie może być rozumiane inaczej niż jako owoc wszechmocnego aktu Boga. Zgoda na takie współdziałanie - jak podkreśla ks. Bajda - jest dla człowieka niezmiernym wywyższeniem.

Działanie rodziny w dziedzinie prokreacji i wychowania potomstwa stanowi wyraźne odbicie stwórczego dzieła Boga Ojca, obraz Boży w rodzinie ujawnia się także w tkwiącej w niej sile twórczej, w miłości, opanowaniu ziemi oraz w bytowaniu społecznym, szczególnie zaś przez wnoszone w życie społeczne przyrodzone i nadprzyrodzone wartości moralne.

Współpraca rodziców z Bogiem w przekazywaniu życia nie kończy się na poczęciu i urodzeniu dziecka, lecz przedłuża się w procesie wychowawczym. To właśnie rodzice z racji zrodzenia i przyjęcia nowego życia „w pierwszym rzędzie mają prawo i obowiązek wychowywać swoje dzieci zgodnie z własnymi przekonaniami”. Są oni bowiem pierwszymi, a zarazem głównymi wychowawcami mającymi zapewnić swoim dzieciom niezbędne warunki wzrostu oraz pełnego rozwoju osobowego i społecznego.

\section{Rodzina szkołą bogatszego człowieczeństwa}

Rodzina, spełniając swą funkcję wychowawczą, staje się pierwszym miejscem humanizacji osoby ludzkiej i społeczeństwa, środkiem edukacji emocjonalnej, tak istotnej dla psychicznej równowagi istoty ludzkiej. W niej to dokonuje się formacja duchowa i moralna człowieka, poza tym dzięki niej człowiek zostaje uzdolniony do wkroczenia i zaistnienia w kręgu innych społeczności, takich jak szkoła, zakład pracy, organizacja, naród, państwo czy Kościół. Dom rodzinny stanowi zatem naturalne środowisko wprowadzania dzieci w życie społeczne, poprzez atmosferę przepojoną miłością i szacunkiem dla Boga i ludzi sprzyja całemu osobistemu i wspólnotowemu procesowi wychowania dzieci i młodzieży. Rodzina jest pierwszą szkołą kształtowania cnót społecznych, koniecznych w prawidłowym funkcjonowaniu wszelkich społeczności.

Poprzez wzajemne wspieranie się małżonków oraz troskliwość okazywaną jednemu pokoleniu przez drugie rodzina staje się szkołą miłości społecznej, 
wyrażającej się w głębokiej trosce i bezinteresownej służbie wobec drugiego, solidarności, sprawiedliwości prowadzącej do poszanowania godności osobistej każdego człowieka, odpowiedzialności, ofiarności, miłosierdzia, odwagi cywilnej oraz patriotyzmu. Dzięki niej człowiek uczy się prawdy i dobra, nabywa świadomości osobowej godności, a rozwijając swe możliwości, swój indywidualny potencjał, przygotowuje się do rozeznania i podjęcia zadań związanych z własnym, niepowtarzalnym powołaniem.

W ten sposób rodzina, w której różne pokolenia spotykają się i pomagają sobie wzajemnie w osiąganiu pełniejszej mądrości życiowej oraz godzeniu praw poszczególnych osób z wymaganiami życia społecznego, jest fundamentem społeczeństwa.

Wspólnota rodzinna winna zapewnić swoim członkom środowisko życiowe, którego głównymi składnikami są: zaspokojenie potrzeb materialnych, poczucie bezpieczeństwa, miłość (czynniki emocjonalne), podstawowe wartości religijne i kulturowe, wreszcie ranga społeczna. Realizacja takiego modelu rodziny stwarza nie tylko szansę zapewnienia jej członkom, rodzicom i dzieciom, rozwoju i dopełnienia osobowego, ale także odegrania przez nich właściwej roli w społeczeństwie i wspólnocie religijnej.

Ważny postulat w tym zakresie podkreślany przez ks. Bajdę to powrót do tradycyjnej kultury, która wychodząc od rodziny i stosunków sąsiedzkich oraz szkoły, uczyła takiego sposobu obecności w świecie, który opiera się na etyce cnoty. Obecnie to dziedzictwo społeczne znajduje się w poważnym kryzysie, ponieważ rodziny usiłujące kontynuować te tradycje, czują jakby wykonywały pracę Syzyfa i ulegają frustracji. To poczucie trudności ilustruje afrykańskie powiedzenie: „żeby wychować dziecko, potrzebna jest cała wioska”.

Misją rodziny bezpośrednio wynikającą z zadania prokreacji i wychowania jest przygotowanie potomstwa do życia społecznego. Rodzina jako społeczność podstawowa łączy osobę ludzką ze społeczeństwem, jest więc niejako pośrednikiem między jednostką a społeczeństwem, pośrednikiem zapewniającym jej identyfikację społeczną, wskazującym również na należną jej rolę i miejsce w społeczeństwie, jest czynnikiem adaptacji i integracji, tak narodowej, jak i międzynarodowej.

W rodzinie, której struktura zapewnia spotkanie i współżycie obu płci, różnych pokoleń, odmiennych osobowości i uzdolnień oraz powołań, tkwią podstawowe wartości społeczne. 


\section{Uczestniczenie w rozwoju społeczeństwa}

Kolejnym zadaniem rodziny jest jej uczestnictwo w rozwoju społeczeństwa. Rodzina jest żywotną i twórczą komórką życia społecznego. Stanowi ona podstawę każdej społeczności, wobec której spełnia najbardziej fundamentalne zadania, a mianowicie gwarantuje jej ciągłość istnienia, odnowę moralną, postęp duchowy oraz rozwój fizyczny.

Rodzina jest nosicielką kultury, przekazicielką norm moralnych i wartości, wśród których priorytetowe miejsce zajmują wartości duchowe.

Dla ks. Bajdy troska o zaangażowanie rodziny w życie społeczne była niezwykle ważna. Podkreślał wielokrotnie, że z więzi rodzinnych jako elementarnych więzi społecznych powstają więzi narodowe, patriotyczne, obywatelskie i inne. Podkreślał, że to w rodzinie tkwią najgłębsze korzenie właściwych postaw sprzyjających życiu społecznemu, takich jak podporządkowanie się wymogom życia społecznego, współdziałanie obywatelskie czy też poczucie odpowiedzialności społecznej.

Wspólnota rodzinna powinna dostarczać doświadczeń przygotowujących do udziału w życiu szerszych zbiorowości - naród, państwo, wspólnotę międzynarodową czy Kościół. Jest ona znakiem porządku społecznego, sprawdzianem dla społeczności politycznej.

Wkład społeczny rodziny ujawnia się także w jej otwarciu na społeczeństwo, podejmowaniu służby społecznej, pomocy okazywanej zwłaszcza osobom ubogim, chorym i cierpiącym, gościnności wobec samotnych i opuszczonych oraz zaangażowaniu w politykę rodzinną i podejmowaniu odpowiedzialności za odnowę moralną społeczeństwa. Życie rodzinne jest więc rzeczywistym wzorem, a zarazem wprowadzeniem w życie społeczne.

Bóg traktuje łącznie, nierozdzielnie, oba zadania powierzone rodzinie: kształtowanie rodziny i panowanie nad światem, troskę o życie i tworzenie historii.

Te nierozdzielne zadania zostały powierzone mężczyźnie i kobiecie: oboje mają wspólnie pracować nad tym, by cele te zostały zrealizowane w sposób prawidłowy. Nakaz skierowany przez Boga do człowieka nie przewiduje żadnego rozdziału na sferę publiczną i prywatną czy też rozdziału kompetencji między mężczyznę i kobietę. Zadania powierzone rodzinie streszczają w sobie istotę powołania ludzkości: nie tylko człowieka jako osoby, ale i całej zbiorowości ludzkiej. Ziemia miała stać się uporządkowanym domem życia, 
poddanym władzy człowieka, a człowiek, organizując życie w harmonii i pokoju, miał podlegać Bogu jako król i kapłan stworzenia, oddający Stwórcy chwałę przez wszystkie swoje dzieła, przede wszystkim przez współdziałanie z Bogiem w kontynuacji dzieła stworzenia.

\section{Troska o właściwe rozumienie pracy}

Ks. prof. Bajda konsekwentnie akcentuje obecność duchowych wartości w pracy. Praca wykracza poza swą wartość wymierną, ponieważ są w niej obecne: miłość, przez którą się realizuje, wolność, innowacyjność i twórczość, która proponuje rozwiązania. Praca pomaga osobom w odkrywaniu swojego życia jako powołania do rozwoju pełni swego człowieczeństwa.

Nowym zjawiskiem $w$ rodzinie jest praca kobiet zatrudnianych na różnych stanowiskach. To może mieć wpływ nie tylko na poziom życia materialnego, ale także na życie duchowe rodziny. Zjawisko to wymaga pogłębienia wzajemnej relacji i komplementarności między mężem i żoną, zrozumienia, że talentami należy się dzielić w życiu konstruowanym na co dzień we wspólnocie. Praca kobiet może stać się inspiracją, jednak pod warunkiem, że małżonkowie świadomie podejmą trud wypracowania głębszej więzi duchowej pomimo zaistniałych obiektywnych trudności.

W tych nowych okolicznościach małżeństwo staje się relacją bardziej personalistyczną, ale też bardziej wymagającą.

Rodzina jest tym podstawowym środowiskiem, w którym osoba ludzka przez całe swoje życie uczy się „sztuki darmowości”.

W swych „Listach” ks. Bajda podkreśla, że darmowość kojarzy się często z czymś, co się czyni za darmo, daje w prezencie, bez zapłaty. Darmowość brzmi sympatycznie, ale jest faktem z marginesu życia ekonomicznego i społecznego. W życiu nie chodzi o przeciwstawienie „daru” praktyce rynku ani o przeciwstawianie „darmowości” temu, co obowiązkowe, ponieważ w życiu istnieją wiele dziedzin, w których dochodzi do uzupełnienia (komplementarności); także kontrakt może popierać wzajemność daru, co często ma miejsce w praktyce ekonomicznej. Tutaj widać, dlaczego rodzina jest miejscem uprzywilejowanym, bo w życiu darmowość się rozwija i jest chroniona. Darmowość oznacza więc, że pewne działanie, postępowanie zostało podjęte tylko dlatego, że jest dobre, a nie dlatego, że doczeka się zapłaty. 
Dzisiaj potrzebny jest także powrót do etyki, odbudowa antropologicznego profilu pracy, a w konsekwencji ukazanie centralnej roli rodziny w odbudowie autentycznie ludzkiego społeczeństwa. Praca wraca do swego źródła, a rodzina - do swego „początku”, z którego wciąż płynie światło.

\section{Rodzina jest powołana do radosnego przeżywania świąt}

Zachodzi istotna różnica między „świętem” a „rozrywką”. Święto jest w jakimś sensie syntezą życia, rozrywka odwraca uwagę od istotnych spraw życia. Dzisiejsze społeczeństwo potrzebuje rozrywki i robi z niej duży biznes, lęka się natomiast święta, ponieważ święto jest sprawą relacji nie podlegających instrumentalizacji i sprawą darmowości, której domeną jest rodzina: są to kategorie nieobecne w wiedzy i praktyce ekonomicznej jako niedające się podporządkować żadnej władzy.

Świętowanie w rodzinie buduje klimat wolny od niepokojących elementów współczesnej kultury. Rodzina powinna troszczyć się o swoją tożsamość chrześcijańską, nie unikając jednak dialogu kulturowego. Warto podkreślić pewne cnoty, które charakteryzują klimat święta. Należą do nich: nadzieja, miłość i radość chrześcijańska, wynikająca z uczestnictwa w tym wielkim dobru, jakim jest zbawienie. Wspólnota rodzinna zanurzająca się w tym klimacie odkrywa spontanicznie czułość jako dar Boga tulącego swe dzieci do serca. Ta czułość udziela się członkom rodziny we wzajemnych kontaktach; czułość jest też uczuciem charakterystycznym dla nich okresie dorastania niemowląt. Ale ta czułość cechuje także odniesienie do osób już dorosłych, eliminując wszystkie elementy pochodzące z motywu przewagi, autorytetu, siły czy wszelkich innych czynników nie uzasadnionych duchową konstytucją rodziny.

W każdej cywilizacji, jak mówią antropologowie, obrzędy służą do tworzenia więzi, umocnienia poczucia przynależności do danego ciała społecznego, do pogłębienia poczucia wspólnoty z czymś, co jest głębsze niż kontrakty i interesy. Rodzina jest główną twórczynią dóbr relacyjnych.

\section{Uczestniczenie w życiu Kościoła}

Zdaniem ks. prof. J. Bajdy podstawowym zadaniem rodziny jest naśladowanie Świętej Rodziny z Nazaretu i czynny udział w życiu Kościoła. 
Rodzinę chrześcijańską często nazywa się Kościołem domowym, małym Kościołem, wskazując tym samym na jej ścisły związek z Kościołem powszechnym. Prawdę tę potwierdza Jan Paweł II w Liście do Rodzin, pisząc że Chrystus wprowadził swój Kościół na drogi ziemskiej egzystencji człowieka, a „pośród tych wielu dróg rodzina jest drogą pierwszą i z wielu względów najważniejszą. Jest drogą powszechną, pozostając za każdym razem drogą szczególną, jedyną i niepowtarzalną, tak jak niepowtarzalny jest każdy człowiek. Rodzina jest tą drogą, od której nie może on się odłączyć"”.

Zadaniem rodziny jest kontemplacja misterium Trójcy Świętej, praktykowanie życia w komunii z Bogiem oraz z bliźnimi na wzór Trójcy Świętej. Zadaniem rodziny jest zgodne przekazywanie prawd wiary, życie we wzajemnej miłości, dzielenie z wszystkimi ich radości i cierpień, wzajemne przebaczanie sobie, wzmocnienie charyzmatów pod kierunkiem duszpasterzy.

\subsection{Troska o uświęcanie siebie i innych}

Jan Paweł II w 1997 roku w Kaliszu podczas homilii w sanktuarium św. Józefa przypomniał chrześcijańskim małżonkom:

sakrament, który was łączy z sobą, jednoczy was w Chrystusie! Jednoczy was z Chrystusem! Tajemnica to wielka! $(E f 5,32)$ Bóg obdarzył was swoją miłością. On do was przychodzi i jest obecny wśród was, mieszka w waszych duszach. W waszych rodzinach! W waszych domach ${ }^{9}$ !

Ks. Bajda, analizując uświęcanie siebie w rodzinie, często podkreślał znaczenie czystości serca. Dar osoby jest prawdziwy wtedy, gdy opiera się na zdobytej cnocie czystości, która daje człowiekowi władzę samopanowania. W odrzuceniu czystości znajduje się właściwy, najgłębszy korzeń degradacji kultury, korzeń odczłowieczenia życia społecznego, źródło pogardy dla poczętego życia, początek tak zwanej kultury śmierci, geneza prądów ideologicznych zmierzających do profanacji małżeństwa, zniszczenia rodziny. Trudno wyrazić słowami skalę tego zniszczenia, którego jesteśmy świadkami, wskutek rozpowszechnienia następstw rewolucji seksualnej. Niezwykle trudnym,

8 Jan Paweł II, List do rodzin, nr. 2.

9 Jan Paweł II, Homilia wygłoszona w czasie Mszy św. odprawianej przed sanktuarium św. Józefa (Kalisz, 4 czerwca 1997 r.), dz. cyt, s. 705 
ale obowiązkowym zadaniem świętych małżeństw jest przywrócenie światu ludzkiego oblicza przez ponowne odkrycie cnoty czystości.

\subsection{Dawanie świadectwa}

Dla ks. prof. Bajdy szczególnie ważne były słowa papieża skierowane w 1997 roku w Ludźmierzu do rodzin wielodzietnych:

W dzisiejszym świecie jesteście świadkami tego szczęścia, które wypływa $\mathrm{z}$ dzielenia miłości, nawet za cenę wielu wyrzeczeń. Nie bójcie się dawać tego świadectwa! Świat może was nie rozumieć, świat może pytać, dlaczego nie poszliście łatwiejszą drogą, ale świat potrzebuje waszego świadectwa - świat potrzebuje waszej miłości, waszego pokoju i waszego szczęścia ${ }^{10}$.

\section{Podsumowanie}

Jedność, harmonia, współdziałanie, jak pisze ks. Bajda w Listach, miały charakteryzować całą historię ludzką. Niestety historia potoczyła się w innym kierunku z powodu grzechu, który wprowadził rozłam, napięcia, nieufność, rywalizację, przemoc, antagonizm, śmierć i zniszczenie. Szczególną katastrofą dla historii stało się zniszczenie harmonii między mężczyzną i kobietą, pociągające za sobą sztuczne rozbicie zakresów odpowiedzialności: podział świata i życia ludzkiego na sferę publiczną i sferę prywatną: publiczną przydzielono mężczyźnie, prywatną oddano kobiecie. Świat został podzielony, ponieważ człowiek został podzielony: ten Człowiek, którego Bóg uczynił Jednością. A człowiek został podzielony, ponieważ został oddzielony od Stwórcy, od Jego Prawdy i Miłości, i ufał jedynie własnemu rozumowi. Pewnym przejawem tego stanu rzeczy jest pozbawienie całych społeczeństw obecności ojca, a w świecie pracy narastają rywalizacja w walce o władzę i kult siły. Tak więc świat woła o „geniusz kobiety”, aby mógł stać się znów domem mieszkalnym.

10 Jan Paweł II, Rozważanie w czasie modlitwy różańcowej (Ludźmierz, 7 czerwca 1997 r.), w: Jan Paweł II, Dzieła zebrane, dz. cyt., t. IX, s. 729. 
Świat wzywa kobiety i mężczyzn, by ich charyzmat duchowy, którymi są macierzyństwo i ojcostwo, spełniał swoją rolę, budując nie tylko rodzinę, która ma ojca, ale także kulturę, która ma matkę. Jest widoczne, że aby uczynić świat ludzkim, trzeba, aby małżeństwo podjęło w pełni swoje autentyczne powołanie.

$\mathrm{Tu}$ - jak podkreśla ks. Bajda - dotykamy najgłębszej istoty rodziny, której nie można zrozumieć wyłącznie w świetle kategorii kosmosu i ziemskich praw przyczynowości. Rodzinę trzeba popierać, ale nie dlatego tylko, że gdy ona słabnie, to społeczeństwo zamiera, ale przede wszystkim dlatego, że Bóg chce nadal objawiać swoją Obecność w rodzinie wiernej swemu powołaniu.

Rodzina stanowi gwarancję harmonijnego rozwoju tak jednostki ludzkiej, jak i całego społeczeństwa, posiada realną zdolność humanizacji konkretnych osób i całych społeczeństw, zapewniając im odnowę moralną, dlatego właśnie społeczeństwo powinno dbać o rodzinę, chronić jej niezbywalne prawa, a w końcu zapewniać prawidłowy, zgodny z jej naczelnymi celami, rozwój.

Rodzina jest szczególnego rodzaju wspólnotą osób złączonych ze sobą więzią miłości daną człowiekowi przez Boga jako swoisty dar, dzięki któremu człowiek zachowuje swoje życie, kształtuje własne człowieczeństwo, wreszcie osiąga dojrzałość, stając się kreatorem kultury i uczestnikiem życia wspólnoty religijnej. Doświadczenie uczy, że cywilizacja i trwałość narodów zależą przede wszystkim od stanu ich rodzin.

Rodzina żyje w świecie, który w dużym stopniu jest przeciwny świętości i oddawaniu czci Bogu. Bóg stworzył ludzi w stanie szczęśliwości, natomiast przez podstęp szatana w życiu ludzkim pojawiły się cierpienie i śmierć. Dopiero po grzechu Adama Pan Bóg zapowiada mężczyźnie „osty i ciernie”, a kobiecie bolesne porody. Ogromna ilość tych cierpień - co wielokrotnie podkreślał ks. Bajda - wynika z grzechów ludzkich, można byłoby ich uniknąć pod warunkiem skutecznej walki z grzechem. W takim razie być może głównym problemem rodzin nie jest zmaganie się z trudnościami i cierpieniami, lecz walka z grzechem, walka o wewnętrzną wolność i duchową odporność, pozwalającą zabezpieczyć się przed atakami szatana.

Nieraz w samych rodzinach gaśnie świadomość świętości życia, małżeństwa, miłości, rodziny - dlatego wiele rodzin ulega wpływowi laicyzmu, naśladując wzory obserwowane w świecie. Dlatego jest czymś niezmiernie ważnym, aby rodziny jako Kościoły domowe ożywiły w sobie świadomość wiary i mocą wiary odbudowały poczucie świętości w całej rzeczywistości 
rodziny, we wszystkich aspektach życia i miłości. Obecność Pana Jezusa należy do istoty rodziny, jej misterium.

Ks. Bajda podkreśla, że wszelkie próby rozmiękczenia rygoru Prawa Bożego i tworzenia koncepcji zastępczych nie pomogły człowiekowi wyzwolić się od kłamstwa, jakie czai się na dnie duszy wskutek lęku przed Bogiem i tym samym lęku przed prawdą. Ks. Bajda dodaje: wszystkie sprawy świata powinny być kształtowane z punktu widzenia prawdy o rodzinie i jej powołaniu otrzymanym od Stwórcy. Świat albo staje się domem rodziny ludzkiej, albo jej grobem.

Rzeczą konieczną jest to, aby rodzina odnalazła w sobie te źródła siły, które Stwórca w niej ulokował, i zaczęła działać mocą swoich charyzmatów. Historia bowiem pokazuje, że żadne instytucje zewnętrzne, żadne zapomogi, zasiłki, ulgi, porady ekspertów i inne tego typu pomoce nie są w stanie zastąpić tego światła i tej energii duchowej, która pozwoliła rodzinie istnieć od początku aż dotąd.

Istotne jest, by wrócić do tej świadomości powołania, które pochodzi od Stwórcy i które pozwala z ufnością oprzeć się na Jego błogosławieństwie danym na początku. I chodzi nie tylko o to błogosławieństwo pierwotne, ale także o to, które nieustannie spływa od Trójcy Świętej przez pośrednictwo Kościoła na te rodziny, które przeżywają swoją więź jako Kościoły domowe. To są moce duchowe, które są silniejsze i trwalsze niż wszelkie moce tego świata.

Tylko tam można mówić o zdrowym rozwoju narodu i jego kultury, gdzie zdrowa jest rodzina i kwitnie szczęście rodzinne. Stąd pierwszym zadaniem państwa w służbie narodu i jego kultury jest służba rodzinie i jej kulturze moralnej.

Przyszłość należy do rodziny, która wierzy w życie stworzone przez Boga i Miłość darowaną w Duchu Świętym, i moc Ofiary Chrystusa, która pokonała śmierć i wszystkich wrogów człowieka. 